\title{
Introduction: an interdisciplinary criminology of international criminal law
}

\author{
I L I A B A N T E KA S
}

\section{Some reasons for the absence of interdisciplinarity in international criminal proceedings}

Whereas the fusion of international criminal law with other disciplines is much more obvious in the context of academic research, principally because of the inroads made by non-legal scholars, the application of these disciplines to international criminal proceedings is rare. One explanation for this is the practical function of international tribunals whose role is to dispense justice to 'real' people. As a result, and given the tight deadlines within which tribunals must process a huge amount of evidence and conduct trial proceedings, they may well claim that they do not have the luxury of experimenting with other disciplines. If this was indeed a valid explanation, tribunals could very well make use of the vast existing literature - as is the case with the reliability of traumatised eye witnesses $^{1}$ - in order to make persuasive arguments concerning the pitfalls of testimony provided by those directly affected by hostilities and violent crimes. ${ }^{2}$ Equally, the tribunals could apply indisputable findings from the natural and medical sciences demonstrating the stresses on human physiology arising from combat. Explanations for the absence of interdisciplinarity in international trials should clearly be sought elsewhere. ${ }^{3}$

1 See, for example, B. L. Cutler, S. D. Penrod, Mistaken Identification: The Eyewitness, Psychology and the Law (Cambridge University Press, 1995).

2 See N. A. Combs, Fact-Finding without Facts: The Uncertain Evidentiary Foundations of International Criminal Convictions (Cambridge University Press, 2011) at 63-105, which explores the decline and pitfalls of oral testimony specifically in the context of international criminal proceedings.

3 To be fair, the ICTY in its early work did seek some expert testimony on evidence reliability, particularly from the late W. A. Wagenaar. See www.icty.org/x/cases/kupreskic/trans/en/ 990603it.htm. See also www.ictytranscripts.org/trials/kupreskic/990603it.htm. Subsequent chambers, however, made little use of these findings. 
The judicial chambers of international criminal tribunals ultimately validate and dictate in what manner the prosecution and defence will present their evidence, including the methods by which such evidence will be presented. By way of illustration, if the judges of a particular tribunal encouraged the application of neuroscience in order to ascertain the mental condition of those claiming exculpatory defences (e.g., duress) then no doubt all future litigants would hire the assistance of neuroscientists and relevant legal arguments would depend on scientific data. In this manner, and in that particular context, the law's construction would be made dependent on extra-legal considerations. As a result, the dynamics of the parties' arguments would shift from legal to extra-legal. At present, such a shift is a fiction in international criminal proceedings (with, it has to be said, some exceptions), but not in other fields of legal inquiry. Neuroscience, for example, plays a central role in the application of an infant's attachment to its parents and the family courts of several nations attribute great significance to attachment theory in their determination of custody and visitation rights. ${ }^{4}$

Why is it, then, that national courts are ultimately receptive to scientific developments in fields such as family and criminal law - not without their fair share of resistance - whereas international criminal tribunals are generally disinclined to consider these at any length? Some personal reflections will be offered to explain this phenomenon, albeit by no means can they holistically disentangle this very complex state of affairs. National courts, as permanent institutions grounded in nation states, are continuously engaged with powerful stakeholders and institutions that exert significant influence upon them, which they cannot lightly ignore. By way of illustration, bar associations, universities, alumni, published research in local or international eminent journals, research by civil society and media coverage are organisations and factors that sway the courts' opinion on several matters, particularly if said matters are not politically contested. The science behind the battered wife syndrome, which is not politically charged, is far more acceptable than the science

\footnotetext{
${ }^{4}$ See the pioneering work of J. Bowlby, Attachment (revised edition, Pimlico, 1997). For an application in family proceedings, see especially, C. George, M. B. Isaacs and R. S. Marvin, 'Incorporating Attachment Assessment into Custody Evaluations: The Case of a 2-Year Old and her Parents', (2011) 49 Family Court Review 483 and A. Schore and J. McIntosh, 'Family Law and the Neuroscience of Attachment: Part I', (2011) 49 Family Court Review 501.
} 
underlying abortions, which remains politically contested principally along religious lines.

These 'pressure groups' are absent in the judicial politics of international criminal tribunals, where the principal stakeholders are the organs that created them and, in some cases, the victim population especially where the tribunal is operating on the territory of the inflicted state. Given that in the vast majority of cases the victim population is largely illiterate and destitute there would be no direct interest in scientific advances outside the courtroom. Local populations would only take issue with the potential impact of particular scientific data on their commonly perceived notions of justice, which are understandably coloured by bias and clan affiliation (e.g., acquittal of an accused on account of his mental state). International bar associations are institutionally weak and members generally view their case loads before international tribunals through a temporary lens; universities and alumni exert little influence given the disparity in the ethnic composition of chambers; the only journals of influence upon the judges are law-related as this is their domain and, as has already been explained, the vast majority of writings on international criminal law in legal journals are not interdisciplinary; the agenda of civil society (at least that of the heavily funded and transnational non-governmental organisations (NGOs)) is largely geared towards anti-impunity (including lawfare) and is disinterested in the introduction of interdisciplinary approaches; and media coverage of the work of international tribunals by the large networks is minimal and hence the judges do not feel any media pressure as such. It is only the local media of the inflicted nations that report extensively, but this hardly exerts significant pressure on foreign judges who do not converse in the local language and see their judicial post as a temporary appointment and perhaps as a step to a subsequent post which is definitely unaffected by local media.

The second explanation for the absence of an interdisciplinary dimension in the work of international tribunals is simply the lack of expertise by lawyers in other sciences and disciplines. ${ }^{5}$ One need only recollect how complex law itself has become, forcing lawyers to become specialists in narrow areas. This is true even in the academic sphere where forays into neighbouring legal disciplines are exceptional for fear of failure and rejection of one's writings. This 'closed' and distorted form of scholarship

5 This is not necessarily true for those with a US-style legal education who will have undertaken a first degree unrelated to law. 
breeds confirmation bias and blocks the emergence of new ideas and methodologies by 'outsiders'. 6 However, the absence of science and humanities in the operation of international tribunals' judicial reasoning is not the result of ignorance on the part of the judges (i.e., ignorance as to the exact science). No judge is expected to follow scientific developments or obliged to infuse law with science. Rather, in their dispensation of justice, judges must (in theory) be open to all those factors that serve justice in the best possible way. Hence, they must invite, rather than oppose, expert opinion on matters that affect the types of human conduct they are determining, in the same manner they employ military analysts to inform themselves of the military structure of the warring parties (e.g., in order to ascertain command hierarchies for the purpose of determining command responsibility). Judges must breed a culture of scientific exchange, inviting expert reports from eminent scientists and should call upon their sponsors to establish a scientific entity that will be charged with the following tasks:

(1) contextual study of each situation (historical, sociological and anthropological);

(2) consult the court and the parties on the available scientific evidence and authorities in respect of a particular issue (i.e., what is the dominant theory on the effects of post-traumatic stress disorder (PTSD) on soldiers in the field); and

(3) arrange for leading experts to offer expert determinations on said issues and assist the court in making sense of scientific data. ${ }^{7}$

The third factor inhibiting international judges' reluctance to introduce extra-legal elements into their judicial reasoning concerns their apprehension of the effects that science may have on judicial outcomes. By way of illustration, if a court had embraced neuroscience which had conclusively

${ }^{6}$ Confirmation bias entails the publication of works endorsed by editors of journals and book series, while rejecting other perhaps better works with which they are not in agreement. For an early empirical exposition of the problem, see J. Mahoney, 'Publication Prejudices: An Experimental Study of Confirmatory Bias in the Peer Review System', (1977) 1 Cognitive Therapy and Research 161.

7 One of the biggest problems in science is the vast diffusion of lab-based results and the lack of inter-connectedness. Biologists, for example, typically study the operation of minute elements in human cells. Although their results are unique they are not directly (or necessarily) related to any particular disease. In the maze of very particular biological discoveries much is lost to medical researchers who are unable to connect every result to a disease. 
demonstrated that combat-wary soldiers, whose physiology had been severely strained, possessed few cognitive powers, it would have no alternative but to determine that the culprits exhibited a diminished intention compared to the typical mens rea requirements of the criminal law. Hence, if non-legal sciences are kept as far removed as possible from the judicial reasoning process the courts decrease the risk of reliance on subjectivity. It is not, of course, that international judges desire unjust outcomes; rather, it is natural to fear that science (including criminological theories) is susceptible to absolute and irreversible results which subsequent judicial reasoning cannot escape without severe criticism. That judges may become slaves to scientific 'truths', dressed in an immutable facade, is as dangerous as uncontrolled judicial subjectivism that is altogether sceptical towards science and criminological thinking. However, no scientific advancement can ever substitute for sound judicial reasoning, because the determination of justice in a particular case requires good use of one's inner faculties. Science can never achieve justice without the intervention of rational faculties. Hence, judges may ultimately decide that the application of a universally accepted theory to the facts of a particular case does not produce just outcomes. Practice has shown that in the few instances where international criminal tribunals have sought expert advice on nonlegal issues - as in the anthropological construction of genocide - they did so with a view to reaching a just result. ${ }^{8}$

\section{Transplanting criminology into the realm of international crimes?}

The principal difference between ordinary (domestic) crime and international crime is context. Ordinary crime involves deviant conduct in a given societal setting that is subject to a degree of control by the local authorities. International crimes, on the other hand, particularly socalled core crimes (genocide, crimes against humanity and war crimes) occur in situations of lawlessness and breakdown of authority. Most transnational crimes, therefore, such as organised crime and terrorism, are akin to ordinary crime as far as their context is concerned. As a result of this diffused context between ordinary and international crimes it is not possible simply to transplant existing criminological theories to explain deviant conduct in the international realm. ${ }^{9}$ The evolution and

${ }^{8}$ Anthropology has generally played a minor role at the ICTY, save for the construction of the pertinent groups susceptible to genocide. See Chapter 9.

9 See Chapter 1. 
application of criminological theories has been largely premised on the notion that criminal conduct is the result of several complex factors; some are attributable to the individual as such (e.g., biological and mental problems and dispositions, aggression theories), but many exist outside the individual and concern his or her interaction with society. Differential association theory, social disorganisation and sub-cultural theory are but a few of the theories that were developed to explain the link between socio-economic circumstances and deviance. Most importantly, criminology has never really dealt with atrocity crimes and the dynamics behind these (such as power relations, broader geostrategic interests etc.), having principally focused on individual deviance. ${ }^{10}$

A criminology of international criminal law, therefore, gives rise to two important questions, namely: (1) Are existing theories on the links between society and deviance still relevant in explaining international crimes, given that in most cases core international crimes occur as a result of the political decisions of a few individuals; and (2) to what extent do we need a new (or perhaps adapted) criminology to address crimes in situations of lawlessness (as in the case of armed conflict), semi-lawlessness (such as piracy and terrorism in failed states) and mass spontaneity (if indeed such spontaneity actually exists) of the type associated with genocide and crimes against humanity independent of armed conflicts?

As to the first question, little empirical research has been conducted to explain why individuals who are not ordinarily exposed to delinquent and deviant behaviour (as per existing criminological theories) exhibit brutal attributes in the context of mass criminality. In the Rwandan genocide even priests participated in the killings, neighbours massacred neighbours and, in the former Yugoslavia, ordinary people turned into heinous torturers. Of course, given that not everyone transforms into a sadistic murderer when mass conflict erupts it is evident that mass criminality and lawlessness do not suddenly awake a latent deviance in all those caught up in it, especially those in positions of power over others. In the Erdemović case, for example, the accused, a conscript in the Bosnian-Serb army, refused to execute unarmed civilians in Srebrenića as did most of his peers. Equally, most Germans rejected Nazi ideology even if they felt powerless to actively resist it. Criminologists have only recently begun to examine such phenomena, ${ }^{11}$ albeit a consistent theory

${ }^{10}$ See the discussion of atrocity crimes in Chapter 1.

11 D. Maier-Katkin, D. Mears and T. J. Bernard, 'Towards a Criminology of Crimes against Humanity', (2009) 13 Theoretical Criminology 227. A. Smeulers and R. Haveman (eds.), 
backed by empirical evidence is missing, as relevant discussions so far have been largely theoretical and of a reconnaissance nature into the realm of international criminal law. ${ }^{12}$ It is certainly worth undertaking a detailed social and psychological profiling of all those mid- to lower-level executioners convicted by international and domestic tribunals in the context of the Yugoslav, Rwandese and Sierra Leone conflicts. Such a study would highlight particular traits common among the perpetrators, their associations prior to the outbreak of hostilities, quality of family life, income distribution, influences from external sources, etc., which, in turn, would possibly point to characteristics shared among the observed group. Hence, the answer to the first question is that criminology does indeed have a role to play in the assessment of characters and their societal interaction prior to the triggering of mass criminality. This process must be adapted to the exigencies of the international crimes under consideration, since the transplantation of existing theories as such is probably inappropriate, albeit certainly the starting point for any subsequent discussion.

As to the second question, significant empirical work has been undertaken by psychiatrists on the physiology and cognitive faculties of those involved in combat. ${ }^{13}$ In a study completed at the close of World War II on US infantry who had fought in northern Europe it was demonstrated that after a period of sixty days of continuous combat, 98 per cent of troops would suffer from a psychological condition, such as acute anxiety, combat exhaustion or depression, whereas the remaining 2 per cent developed an 'aggressive psychopathic personality' on the basis of which they could endure long periods of combat without any of the aforementioned symptoms common to the majority of their comrades. ${ }^{14}$ Even so, we are still unaware of the effects of combat or non-organised violence on civilians-turned-combatants, or the impact of one's socioeconomic history in the context of lawlessness. Equally, anthropological

Supranational Criminology: Towards a Criminology of International Crimes (Intersentia, 2008), have called for the establishment of a 'supranational criminology' for the purpose of examining mass international crimes.

12 See, for example, N. Theodorakis and D. P. Farrington, 'Emerging Challenges for Criminology: Drawing the Margins for Crimes against Humanity', (2013) 6 International Journal of Criminology and Sociological Theory 1150.

13 D. Grossman and L. Christensen, On Combat: The Psychology and Physiology of Deadly Conflict in War and in Peace (PPCT Research Publications, 2008).

14 R. L. Swank and W. E. Marchand, 'Combat Neuroses, Development of Combat Exhaustion', (1946) 55 Archives of Neurology and Psychiatry 236, at 244. 
data reflecting the views among the warring factions of a conflict are typically collected after the eruption of violence and, as a result, we possess a foggy picture as to the social relationships between victims and attackers at various temporal periods prior to the outbreak of hostilities. If we did possess such data, by means of early warning mechanisms, criminologists would be able to assess at what point in time social relations deteriorate. This would provide them with an opportunity to pinpoint those factors that exacerbate or ignite the change of circumstances, such as acute propaganda, high concentration of criminal elements in positions of authority, or other factors. Criminologists could then inform policy makers but also come to grips with those factors that trigger large social meltdowns that lead to mass unrest and criminality. ${ }^{15}$

It is clear, therefore, that the transplantation of existing criminological theories into the realm of international crimes - save for most transnational crimes - is inappropriate for addressing the multifaceted dimensions of these offences and their particular contexts. The social, anthropological and psychological context of international crimes demands new methodological approaches and new theories that link the individual to mass spontaneous phenomena.

\section{Designing an appropriate research agenda}

The organisation of the chapters in this book reflects a very specific thinking about what should be encompassed in a supranational (or international) criminology. This author does not view the aforementioned core crimes as the only international crimes, as they do not exist in isolation of other so-called transnational crimes, ${ }^{16}$ such as terrorism, organised crime, corruption etc., which almost exclusively feed, to a larger or smaller degree, international conflicts and mass criminality. ${ }^{17}$

15 In the Rwandese conflict, propaganda was a major tool in the hands of the genocidaires and at some point all transmission by radio was blocked through concerted international effort. See J. F. Metzl, 'Rwandan Genocide and the International Law of Radio Jamming', (1997) 91 American Journal of International Law 628.

16 For a discussion as to their distinction, see I. Bantekas, International Criminal Law (4th edn, Hart, 2010), at 9.

17 'A Comprehensive Report of the Security Council-appointed Panel of Experts on the Illegal Exploitation of Natural Resources and other Forms of Wealth of the Democratic Republic of the Congo underlined the direct or indirect implication of 157 corporations, the operations of which fueled the purchase of arms, the perpetration of war crimes and crimes against humanity and the exploitation of Congo's natural resources to the detriment of its people.' Letter dated 23 October 2003 from the Secretary-General 
Going a step further, terrorism and corruption, among other crimes, have been found to produce the same effects as war crimes and crimes against humanity. ${ }^{18}$ As a result, while victimologists do undertake research on the effects of particular international crimes, ${ }^{19}$ they are typically concerned with objective criteria, such as mortality rates and particular criminal incidences. Four broad phases are identified in a criminological study of international crime, namely:

(1) establishing context and understanding criminal conduct from multiple perspectives;

(2) investigation of crime by examination of available evidence;

(3) collaboration and enforcement through the use of appropriate and legitimate techniques; and

(4) transitional justice.

The first three phases are directly relevant to the work of international criminal tribunals, whereas the fourth concerns policy makers. By comparison, context is largely irrelevant to domestic criminal proceedings and there is no equivalent to transitional justice other than a generalised crime policy. Moreover, the degree of collaboration among institutions in a single nation is far more effective, less complex or cumbersome as compared to cooperation between states or institutions at the international level.

Anthropology and state crime studies reveal practical and theoretical approaches to context which are not obvious to the enforcer of law. In the Sierra Leone conflict, admission of cannibalism by the culprits was found to possess an altogether metaphorical meaning, ${ }^{20}$ whereas accidental deaths caused by an earthquake may be attributed to the negligence of the state through its failure to enforce the highest standards of diligence upon its construction industry. ${ }^{21}$ Neuroscience and psychology offer useful insights into the context of an armed conflict and explain from a clinical perspective the conduct of the persons involved in mass criminality. $^{22}$

addressed to the President of the Security Council, UN Doc S/2003/1027 (2003), paras. $10-13$.

18 A. Cassese, 'The Multifaceted Notion of Terrorism in International Law', (2006) 4 Journal of International Criminal Justice 933.

19 As is the case with Chapter 12 of this book, which examines victimisation in the context of armed conflicts and war crimes.

20 See Chapter 9. ${ }^{21}$ See Chapter 3. $\quad{ }^{22}$ See Chapters 8 and 10. 
Examination of evidence is the bread and butter of criminal proceedings. A detailed study of context will have already provided a solid basis for reading the available evidence. Although the methodology will largely remain the same, there are crucial differences between the construction of evidence before international criminal tribunals and other courts. International tribunals typically prosecute senior figures and, as a result, prosecutors therein must link the criminal conduct of mid- and lowerlevel executioners to their source and inspiration. Moreover, eye witnesses may be in the thousands and forensic evidence will be extensive, including scores of rape and mutilated victims, displaced communities and mass graves. Victims and witnesses will have to return home at the end of their testimony, perhaps in close proximity to the friends and allies of the person they testified against. Unlike ordinary crime the majority of the culprits will perceive their role from a gallant lens, reinforced by notions of nationalism, patriotism, religious mission etc., which naturally dissolves their sense of guilt, even in respect of the most heinous crimes. This is further augmented by popular perception of the culprits' heroic image and their contribution to the group as such. As a result, oral testimony in mass criminality cases may be misleading due to the fact that an entire class of witness colours events, even heinous acts, according to its particular view and does not attach the requisite degree of importance to conduct as do the prosecutor or the judges. Equally, although much research has taken place on urban gangs and domestic organised criminal groups, as well as terrorist organisations, little work has been undertaken on the organisational aspects of mass crime organisations of the type involved in the context of the International Criminal Tribunal for the former Yugoslavia (ICTY), International Criminal Tribunal for Rwanda (ICTR) and the Sierra Leone Special Court (SLSC). ${ }^{23}$ International tribunals have used abstract and, to a large degree, arbitrary legalistic criteria to explain participation in 'groups' engaged in genocide and crimes against humanity and have, as a result, developed concepts such as joint criminal enterprise (JCE) in order to achieve justice. These concepts have not, however, been tested from a criminological perspective and, hence, there is uncertainty as to whether participants share the same goals, motivations or intentions.

The theme on collaboration and enforcement concerns the field of transnational criminal law and not the work of international criminal

23 See O. Olusanya, 'A Macro-Micro Integrated Theoretical Model of Mass Participation in Genocide’, (2013) 53 British Journal of Criminology 27. 
tribunals. Here our concern is with strategies and policies of prevention and of making the best possible use of technology to detect crime in circumstances where the culprits make a concerted effort to cover their tracks. For example, lawyers involved in piracy prosecutions are missing that part of the puzzle which seeks to understand the motivations behind large-scale piracy off the coast of Somalia and the policies involved to contain, deter and eliminate the phenomenon as a whole. Given that piracy jure gentium has a direct impact on the global shipping industry and has itself become a very lucrative enterprise that sustains a nation ${ }^{24}$ as is the plundering of a country's natural resources by warlords - it is evident that the relevant policies are international in nature. Moreover, the use of technology is underestimated in the context of transnational criminological approaches. Its utility is virtually endless, so here we concern ourselves with a particular application of information systems theory (IST) to terrorist financing, organised crime and money laundering, the detection of which by financial institutions (who are obliged to act as gatekeepers, among others) is extremely difficult. ${ }^{25}$ They are burdened with a duty to report all suspicious transactions (above a particular monetary threshold) and it is understandable that this is a massive task given the number of daily transactions processed by financial institutions across the world. Without the assistance of information systems (IS) this task would resemble looking for a needle in a haystack. These sort of algorithmic-based databases are crucial to stemming the flow of finances to criminal organisations and are ultimately an important tool not only for UN Security Council-based sanctions committees, but also for relevant freezing policies against all warlords and leaders engaged in mass crimes against their people.

Finally, in recent years, starting with the UN-backed Latin American truth commissions of the 1980s and continuing with the aftermath of the Yugoslav and Rwandese conflicts, part of the emphasis of the international community has shifted from punishment to restorative justice. ${ }^{26}$ There are cogent reasons for encompassing transitional justice in the realm of criminology, rather than treating it as merely an element of

24 See E. Papastavridis, 'Piracy off Somalia: The Emperors and the Thieves of the Oceans in the 21st Century', in A. Abass (ed.), Protecting Human Security in Africa (Oxford University Press, 2010), at 122.

25 See Chapter 7.

${ }^{26}$ See P. B. Hayner, Unspeakable Truths: Transitional Justice and the Challenge of Truth Commissions (2nd edn, Routledge, 2011). 
international politics. It is unthinkable that criminologists and policy makers in the criminal justice field would not devise a system of containment and deterrence in the aftermath of a protracted and violent civil conflict where heated passions and sentiments naturally persist. This can only be achieved through a long-term combination of retributive and restorative justice actions that are designed and executed at the highest level. Here, we examine the position of the victim in transitional justice mechanisms and the adaptation of victimology to international crimes. ${ }^{27}$ Although the criminological dimension of transitional justice depends on external funding, the success of any policy, as such, principally rests on the will of the international community. The latter's political pressure on the local parties to uphold their obligations constitute a significant aspect of any such policy.

These four phases to a criminologically informed investigation of international crimes require a variety of expertise in the humanities, technological, social and medical fields. No single scholar can undertake the task on his or her own. Although not all these phases will be relevant to a judge, prosecutor or defence counsel before an international or domestic tribunal dealing with international crimes, they should inform every international criminal justice policy initiated by intergovernmental organisations or coalitions of states.

\section{A discussion of the chapters in this book}

Chapter 1, by Andy Aitchison, responds to the question: 'What can criminological theory contribute to scholarship in international criminal law?' Before answering that question, the chapter recognises criminology as a relative latecomer to the study of atrocity, highlighting the apparent incongruity of a discipline with a strong mainstream theoretical and methodological focus at the individual level on the one hand, and a set of phenomena characterised by systematic organisation and mass participation. John Hagan and Wim Huisman are presented as exemplars of the current criminology of atrocity, identifying respectively the value of a sociological, structural criminology and the applicability of frameworks derived from research on organised forms of criminality. Three further areas of criminology are explored as a potential basis for further development. A Durkheimian perspective suggests merit in examining the 
uneven development of a 'global society'. A victimological approach points to the benefit of comparative analysis of atrocities and of contexts marked by entrenched cleavages and inequalities but which do not feature atrocity. Finally, techniques of neutralisation are examined as an example of a perpetrator-oriented framework. This highlights the need for caution in utilising more individual-level analyses. Careful attention to social processes means that an alternative terminology of temporary deviant normative orders is more appropriate than the neutralisation of a conventional morality. Criminological theory is beginning to make a contribution to international criminal law scholarship and has the potential to develop this further.

Chapter 2, by Emmanouela Mylonaki, examines the application of social science research methods to the study of international crimes and international criminal law. Traditionally, criminologists have focused on common crime and violence, rejecting the idea that violations of international criminal law offer substantial theoretical and practical interest to the discipline of criminology. However, the evolution of international crimes and the frequency of crimes such as international terrorism, genocide and crimes against humanity present important intellectual challenges for criminological theory and research. By studying the causes and motives of those involved either as perpetrators or victims, the situations in which such crimes are committed, and their inherent dynamics, criminologists can unravel many of the complexities in the development and proliferation of such activities across the world and by doing so avoid any irreversible short term legalistic solutions.

There are several major research tools available to traditional criminology, such as field research and survey research. Each one of these poses particular difficulties. For example, field research presents physical dangers, while survey research is complex because it would be difficult to obtain anything but availability samples. Chapter 2 focuses on the practical application of empirical research methods in international criminal law by providing insights into the process of gaining access to sources and the different ways in which data can be collected and analysed for research on international crime and international criminal justice. In particular, the chapter deals with quantitative and qualitative research methods. It examines the extent to which criminological research methods can assist in explaining the persistence of international crimes and suggests how criminological research methods could inform the central issues of crime in the international context. The chapter is divided into two sections. The first highlights the relevance of the 
application of criminological research methods to the study of international crimes and gross violations of human rights and reinforces the arguments for the inclusion of the notion of international crimes within the realm of empirical research. The second demonstrates the practical application of quantitative and qualitative research methods in the study of international crimes and indicates the areas where empirical research is relevant.

Chapter 3, by Kristian Lasslett, discusses the notion of state crime. In a challenge to orthodox criminological understandings of what constitutes crime, and who can legitimately sanction wrongful behaviour, over the past two decades criminologists have paid increasing attention to crimes committed by states and the movements of resistance that emerge in opposition to deviant state practice. At the heart of this new criminological sub-discipline is an interest in the social configurations which cause states to exceed accepted rules of conduct and the factors that prompt victims and civil society to define these actions as criminal and then actualise censure through acts of sanction. In order to acquaint readers with critical features of the emerging terrain in state crime studies, Chapter 3 begins by examining the particular conceptual frameworks criminologists employ to define state crime - particular attention being paid to criteria-based and process-driven approaches. It suggests that although the former framework illuminates breaches of normative criteria, the latter approach is more attuned to the practical processes of historical struggle that stigmatise state practices as criminal. Attention is then turned to criminology's growing interest in the forms of social resistance state crime prompts. It is suggested that this stream of inquiry offers a conduit through which to consider the broader economic, political and ideological fault-lines upon which state crime and resistance rest, a conduit that allows scholars to concretise understandings of why states exceed certain normative boundaries and why communities of resistance are strategically disposed to stigmatise these actions as criminal. Finally, the chapter considers the different theoretical traditions criminologists have employed to understand these fault-lines, looking in particular at the strengths and limitations of positivist versus Marxist approaches. It is concluded that state crime studies offer a powerful vantage point through which to inquire into, and articulate, the way different configurations of civil society produce, through struggle, normative boundaries which states must adhere to, and then enact sanctions when these boundaries are exceeded, in addition to illuminating the factors that inspire states to exceed these normative boundaries and eschew subsequent stigmatising 
labels, looking at the potential this complex social exchange has for producing emancipatory forms of social change.

Chapter 4, by Jonathan Rusch, discusses the problems and techniques associated with the investigation of complex crimes, the vast majority of which are either transnational or international in nature. Successful criminal investigation requires the use of lawful investigative methods to gather evidence that is available to investigators and appropriate for the type of evidence needed. Because certain types of crime are notably more complex than others, police or investigative agencies need to use a wider array of investigative methods and techniques to be successful at investigating those crimes. Chapter 4 first describes the leading characteristics of complex crime:

(1) groups committing the same types of crime over an extended period;

(2) geographic and functional dispersion of operations;

(3) targeting of multiple victims;

(4) use of false or fraudulent statements and withholding of material information in furtherance of crime;

(5) counter-intelligence and counter-surveillance measures and measures to obstruct investigations; and

(6) threatened or actual violence.

It then identifies and examines the principal investigative methods and techniques that law enforcement agencies use to investigate complex crime. These include:

(1) interviews of witnesses;

(2) surveillance;

(3) acquisition of documentary evidence;

(4) testimony of eyewitness or third-party witnesses;

(5) use of confidential informants and criminal participants;

(6) use of undercover agents; and

(7) electronic surveillance.

The chapter provides examples from a number of criminal operations with particular reference to drug trafficking organisations (DTOs), organised-crime groups and mass-marketing fraud and other economic-crime networks - to explain the relevance and value of each of these methods and techniques. It also examines various international conventions and domestic legal measures by which nations conducting investigations of complex crime can secure cooperation from other nations to obtain evidence of complex crime. 
Chapter 5, by Dermot Groome, examines the collection, administration and use of evidence in mass crime cases, particularly from the perspective of the prosecutorial team. International crimes are most often the result of collective action and may involve the co-opting of state institutions for criminal purposes. Domestic crimes can be elevated to international crimes when committed on a widespread or systematic basis as part of an attack on a civilian population. Identifying and collecting the evidence necessary to establish this additional element presents challenges that are different from domestic prosecutions. Chapter 5 examines the search for evidence establishing international crimes; the conceptual and practical differences between collecting evidence for international, transnational and national crimes; and the relationship between international courts and states in possession of relevant evidence. It considers different sources of potential evidence, including legislative materials, minutes of state organisations and statements of senior political leaders. The chapter examines all of these issues in the context of adjudicating both individual and state criminal responsibility.

Chapter 6, by Brian Cutler, Rod Lindsay and Andrew Smith, focuses on the role and psychology of eyewitnesses in international criminal trials. In recent decades, global recognition of wrongful convictions has increased. DNA-based evidence conclusively confirms that wrongful convictions do occur. Catalogues of known wrongful convictions find that mistaken eyewitness identification is the antecedent most commonly associated with wrongful conviction. ${ }^{28}$ Approximately 50 per cent of known wrongful convictions were preceded by mistaken eyewitness identification. ${ }^{29}$ Although alleged perpetrators of international crimes are often known to eyewitnesses, identification errors may still occur. Errors in memory may occur at the time of perception or anytime thereafter. In Chapter 6, the authors examine the identifications of Clément Kayishema and Obed Ruzindana, both of whom were convicted of genocide at the ICTR. ${ }^{30}$ The authors believe that the eyewitness evidence is compelling on the whole and do not suggest that either

28 S. R. Gross and M. Shaffer, 'Exonerations in the United States, 1989 - 2012: Report by the National Registry of Exonerations', (2012) 1, The National Registry of Exonerations, available at www.law.umich.edu/special/exoneration/Documents/exonerations_us_1989_ 2012_full_report.pdf;A. M. Smith and B. L. Cutler, 'Introduction: Identification Procedures and Conviction of the Innocent', in B. L. Cutler (ed.) Reform of Eyewitness Identification Procedures (APA, 2013).

29 Ibid.

${ }^{30}$ ICTR Prosecutor v. Kayishema and Ruzindana, judgment (21 May 1999). 
Kayishema or Ruzindana is innocent of genocide; however, the case provides several opportunities to discuss the conditions under which identification accuracy is likely and provides a framework for discussion of several potential errors in memory. The authors begin their analysis by questioning the utility - or lack thereof - of in-dock identifications. ${ }^{31}$ In further discussion of the case, they consider eyewitness and target characteristics including memory for in-group versus out-group persons, the age of the eyewitness, source misattributions and fatigue. They also consider event characteristics, such as stress and perpetrator visibility (e.g., lighting, distance and disguise), and how, under conditions of low visibility, expectancies may guide correct or incorrect recognition. They go on to consider the length of exposure and the delay between witnessing the event and remembering. Subsequently, they discuss the potential for post-event information to alter the eyewitness's memory of the perpetrator. In doing so, they examine the moderators, including age and attention, and the sources of post-event information, including additional eyewitnesses and interviewer suggestion. Finally, they conclude the chapter with a review of best-practice interviewing techniques.

Chapter 7, by Dionysios Demetis, examines a variety of IS influences on the prevention and detection of criminal behaviour. First, the chapter delineates the basic information principles that surround the technological manipulation of large datasets. These essentially constitute databases that are profiled, algorithmically manipulated and used in order to distil actionable information for preventing criminal behaviour. Basic principles of profiling and data mining are described, while implications that stem from the phenomenon of data growth are analysed. Data growth is important, as the central problem of using IS for preventing criminal activity is anchored on the mass of data that requires processing, manipulation, categorization and analysis. These processes construct the basis upon which different data types become computationally malleable and form the ground that gives rise to the power of algorithms. The complexity that emerges out of the interaction of technology with its socio-economic and political context becomes further deconstructed with the use of examples. The role of international-level IS influences is discussed through a brief analysis of Europol's information systems. Furthermore, the chapter focuses on the domain of money laundering in order to describe the impact technology has had on flagging suspicious

31 Ibid., para. 457. 
activity. As a result of this analysis, general themes in the organisation of technology and criminality are highlighted, while a theoretical framework is presented that deconstructs the most important dimensions in the profiling of suspicious behaviour with the aim of synthesizing these into a coherent structure.

Chapter 8, by Olaoluwa Olysanya, examines the dynamics of participation in mass violence through the perspective of the macro-micro integrated theoretical model (MMITM). Extreme forms of collective violence, such as genocide and crimes against humanity, involve organised and goal-directed one-sided acts of violence by members of an aggressor group against members of a targeted group in order to achieve specific objectives. Logic would dictate that variables such as group size, task type (e.g., committing murder or torture), group climate and group cohesion will have an impact on effectuating collective violence. The reality is that perpetrators of genocide and crimes against humanity, especially at the outset, represent a highly heterogeneous group with different beliefs, emotions and attitudes towards members of a targeted group. In essence: 'the good the bad and the ugly'. These three disparate subgroups, despite their differences, at some point in the course of destructive events, appear to work together to achieve a common criminal objective. From this perspective, it becomes important to recognise that collective violence involves associations between three distinct subgroups of individuals whose journey into collective violence can be traced back to disparate origins. How are these disparate groups of people brought together for the duration of a specific, time-limited criminal project? How do we evaluate the fit of each individual in terms of his or her likelihood of following each offending trajectory? How do we trace these distinct offending trajectories? And how is evil unknowingly perpetrated by the 'good', who clearly constitute the majority of perpetrators? These issues have been largely ignored by criminologists. Also there is some doubt as to whether criminological theories that were originally designed to explain domestic crimes can be extended to explain organised and goal-directed large-scale acts of violence. The MMITM was developed to explain the latter category of crimes. Chapter 8 aims to demonstrate how the MMITM can help shed light on these complex issues.

Chapter 9, by the present author, discusses the theoretical as well as the practical application of anthropology and its methods in the field of international criminal justice. For far too long the prosecution of serious international crimes, particularly genocide and crimes against humanity, 
was undertaken without any research on the context or the culture of the actors involved. The work of the ICTR has shown that legal definitions and concepts are inconsistent with established knowledge in anthropology, the humanities and medical sciences. As a result, the construction of existing treaties by judges dealing with international crimes can only be achieved by reference to culture. However, given that culture is local, constituting a phenomenon which cannot be understood by outsiders without significant anthropological research, it is evident that international prosecutions of crimes require contextual analysis. The author offers numerous examples whereby the courts implicitly conceded the inadequacy of existing law or otherwise realised (or not, as the case may be) that the literal translation of words and sentences from one language to another fails to encapsulate or convey other shared meanings behind those words. It must become imperative for international tribunals to hire anthropologists knowledgeable in the cultures under investigation before any case reaches the bench.

Chapter 10, by Henrik Anckarsäter, Tova Bennet, Thomas Nilsson and Susanna Radovic, examines the perspective of neuroscience and psychiatry on international criminality. It is now firmly established that mental disorders - just as social disadvantages - have probabilistic relationships with crimes. Established risk factors for violent crimes include first, and most importantly, previous criminal behaviour of the individual, but also gender, age at onset, substance abuse, attentiondeficit hyperactivity disorder (ADHD) and antisocial personality disorder. The current state of knowledge includes very few, if any, systematic studies of psychiatric factors on perpetrators of international crimes. International crimes differ from general violent criminality in several respects. They are more often performed in a social context of perpetrators rather than alone and are dependent on societal power structures. They would be thought to be more related to ideologies and thought content rather than driven by personal gain. This means that for forensic psychiatry the general importance of childhood-onset conduct disorder, substance abuse and ADHD or similar diagnoses of impulsivity will probably not be central in the context of international crime. Instead, disorders of social dynamics and thought content will come to the forefront.

The authors start by giving a brief presentation of the insanity defence in the context of the International Criminal Court (ICC), and then move on to discuss whether an insanity defence should be included in international law. They further discuss on what grounds a person should be 
acquitted due to insanity when it comes to mass atrocity crimes. In this context they especially focus on thought disorders. The classic disorder of thought content is paranoia. In autism spectrum disorders, thought content is also affected but in a different way. Generally, autism, like paranoia, is thought to decrease the possibility of successful social interaction, but may confer 'charisma' to individuals operating in strictly hierarchical organisations. The social disability in autism specifically hampers reciprocal interaction, but may not be evident in command interaction.

Chapter 11, by Jeffrey Stevenson Murer, explores the motivations for joining violent groups across a range of circumstances. In particular, the chapter explores the similarities in the role of violence as a marker of identity within groups as diverse as street gangs and ethnic communities. Frequently, membership in violent groups is explained in terms of individual material gain or the attainment of individual fame in very rationalist and individualistic terms. These violent encounters or employments of violence by young people are often defined as being interpersonal in nature; that is, the motivation to use or not use violence is held by a single individual, expressing individual agency in making a choice whether or not to deploy violence. This focus on individual choice and motivation has likewise been extended to studies of terrorism and rationalist interpretations for the motivation to participate in civil wars or other armed conflicts. Indeed, many of these studies treat joining these violent groups and the deployment of violent acts as being antisocial, as if the choice to engage in violence is one wholly against social norms or social values. However, much can be gained by seeing these groups in completely the opposite light: gangs, communal factions, militias, even terrorist organisations can be seen as highly social environments, especially for those who feel that they have limited opportunities for social capital accumulation or mobility within larger society, or indeed have even been expelled from a mainstream social mobility milieu altogether. Within such social milieus violence is but one form of social action among a whole range of social acts; or, to put it more succinctly, in such circumstances violence itself is a social act. Chapter 11 examines the performative qualities of violence and the role that violence plays in the experience of belonging in large groups and in collective identity formation.

Chapter 12, by Amissi Manirabona and Jo-Anne Wemmers, examines the victimology of war crimes. Despite the growing number of studies in victimology in recent years, relatively little attention has been paid to the 
development of classification systems in this field. Chapter 12 reviews existing typologies and points at their primary limitation, namely their narrow definition of victims. Increasingly, we have come to realise that crime not only impacts the individual who is the direct target of a crime but can also affect their family, friends and community. Moreover, following the creation of the ICC, which typically deals with mass victimisation such as war crimes, it is clear that classical models which focus on one victim fail to take into account the complexity of wartime victimisation and its effects. A typology of victims is proposed based on the victims' emotional or psychological proximity to the crime. The value of this typology is that it allows us to identify the different types of consequences which different categories of wartime victims may experience and, therefore, better identify their needs. Using this typology the authors address the needs of wartime victims with respect to reparation. The chapter closes with recommendations for reparation in the context of the ICC. 